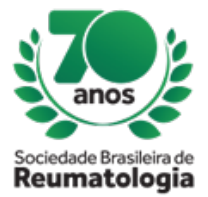

\title{
CROHN'S DISEASE-LIKE GASTROENTERITIS AS ONSET MANIFESTATION OF EOSINOPHILIC GRANULOMATOSIS WITH POLYANGIITIS (EGPA)
}

Elisa Fernandes de Melo (Universidade de Taubaté, Taubaté, SP, Brasil), Raylane Shellyda de Almeida Anate (Universidade de Taubaté, Taubaté, SP, Brasil), Vinicius Verlangieri Soubihe (Universidade de Taubaté, Taubaté, SP, Brasil), Natália Engler Ravasio (Universidade de Taubaté, Taubaté, SP, Brasil), Jose Roberto Megda Filho (Universidade de Taubaté, Taubaté, SP, Brasil), Amauri Marcelo Cisotto Rocha Junior (Universidade de Taubaté, Taubaté, SP, Brasil), Paulo Giovanni Estevam (Universidade de Taubaté, Taubaté, SP, Brasil), Felipe José dos Santos Pereira (Universidade de Taubaté, Taubaté, SP, Brasil), Pedro Luiz Homem de Mello (Universidade de Taubaté, Taubaté, SP, Brasil), Drielle Rezende Pavanitto (Universidade de Taubaté, Taubaté, SP, Brasil), Tainara Mariana Ferreira Leismann (Universidade de Taubaté, Taubaté, SP, Brasil), Daniel Renato Gonçalves Duarte (Universidade de Taubaté, Taubaté, SP, Brasil), Glenda Alves Pereira de Oliveira (Universidade de Taubaté, Taubaté, SP, Brasil)

\section{BACKGROUND}

EGPA is characterized by airway inflammation, hypereosinophilia in the blood and tissues, formation of extravascular granulomas, and vasculitis of multiple organ systems. The necrotizing inflammation affects small-caliber vessels, being classified as vasculitis with ANCA-positive. The histopathological aspect consists in the occurrence of granulomatous reactions, which may be present in the tissues and vessels. They are usually associated with tissue infiltration by eosinophils. This process can occur in any organ of the body, predominantly pulmonary involvement with the presence of infiltrates and severe asthmatic crises. The gastrointestinal tract may be involved, simulating inflammatory bowel disease. When untreated the disease presents a reserved prognosis, but can have an increase in the survival rate when treated.

\section{CASE REPORT}

Female, 53 years old, hospitalized due chronic dysentery, abdominal pain and peripheral neuropathy. Reported a history of an asthma of difficult control during adult life, beginning at age 26. Laboratorial tests showed anemia with leukocytosis ( 30.200 cells with 57\% eosinophils), thrombocytosis, ESR of 91 and negative serologies for HIV, hepatitis B and C. Submitted to gastrointestinal endoscopy and colonoscopy, in which multiple ulcerated lesions were visualized in the stomach and colon, and the biopsies resulted in inflammatory processes, compatible with Crohn's disease. Started prednisone $1 \mathrm{mg} / \mathrm{kg} / \mathrm{day}$ with partial improvement, however, it presented worsening of the peripheral neurological condition. An electroneuromyography was compatible with multiple mononeuritis. The diagnosis was confirmed for EGPA considering a positive p-ANCA, despite the anti-MPO and anti-PR3 negatives. The patient initiated methylprednisolone pulse therapy and cyclophosphamide, with significant clinical improvement.

\section{CONCLUSION}

EGPA is an ANCA-associated vasculitis characterized by airway inflammation, hypereosinophilia and vasculitis of multiple organ systems. Clinical manifestations may be diverse, with pulmonary findings being the most predominant and multiple mononeuritis being the second most common manifestation, occurring in up to $72 \%$ of patients. The gastrointestinal symptoms are like Chron's disease. Although the diagnosis is ideally established by biopsy, in a patient with characteristic clinical manifestations, histological confirmation may represent a challenge, since pathognomonic manifestations do not often occur simultaneously. This should not delay the treatment due to the severity of the condition. Isolated glucocorticoids appear to be effective, but in case of failure, or when the patient has a multisystemic disease, the choice treatment is Cyclophosphamide. 